\title{
HUBUNGAN BERPIKIR KRITIS DENGAN KREATIVITAS SISWA MELALUI MIND MAP PADA PEMBELAJARAN BIOLOGI
}

\author{
Usman $^{1)}$, Enggar Utari ${ }^{2)}$, Nourma Yulita ${ }^{3)}$ \\ ${ }^{1) 2)}$ Pendidikan Biologi, FKIP Universitas Sultan Ageng Tirtayasa, \\ ${ }^{3)}$ Tadris IPA, Fakultas Tarbiyah dan Ilmu Keguruan, IAIN Kendari, Sulawesi tenggara \\ email $^{1)}$ : usman@untirta.ac.id \\ email $^{2)}$ : enggar.utari@untirta.ac.id \\ email $^{3)}$ : nourmayulita@iainkendari.ac.id
}

\begin{abstract}
ABSTRAK: Penelitian ini bertujuan untuk mengetahui hubungan kemampuan berpikir kritis dengan kreativitas siswa melalui mind map. Metode penelitian yang digunakan adalah metode deskriptif korelasional. Penelitian dilaksanakan di SMAN 5 Kota Serang kelas X MIPA 5 semester 1 tahun ajaran 2019/2020. Teknik pengambilan sampel yang digunakan adalah random sampling. Pengambilan data penelitian menggunakan instrumen berupa soal uraian kemampuan berpikir kritis dan lembar penilaian kreativitas dalam membuat mind map. Hasil penelitian menunjukkan bahwa rata-rata kemampuan berpikir kritis siswa berada pada kategori cukup dengan persentase sebesar 35,48\% dan kreativitas siswa yaitu 64,52\% dengan kategori cukup. Nilai koefisien korelasi $\left(\mathrm{r}_{\mathrm{xy}}\right)$ yang diperoleh dalam penelitian ini yaitu sebesar 0,427 . Korelasi tersebut menunjukkan bahwa tingkat hubungan antara kemampuan berpikir kritis dengan kreativitas siswa berada pada kategori sedang.
\end{abstract}

Kata kunci: Berpikir kritis, Kreativitas, Mind map.

ABSTRACT: This research is purposed to find out about relation of critical thinking ability with student creativity to mind map. The study used descriptive correlational method. This study was conducted in SMAN 5 Serang City class X MIPA 5 school year 2019/2020. The sampling technique use was random sampling. Research data collection using instruments in the form of question about the ability critical thinking and creativity assessment sheets in making mind map. The result showed an average ability of critical thinking in the enough category with a percentage of $35,48 \%$ and student creativity that is $64,52 \%$ with enough category. The correlation coefficient values obtained in this study was 0,427. Correlation shows that the level relation between critical thingking ability with student creativity in medium category.

Keywords: Critical thinking, Creativity, Mind map, biology learning.

\section{PENDAHULUAN}

Pendidikan menjadi ujung tombak dalam mempersiapkan generasi muda masa depan agar mampu menjawab tantangan zaman. Salah satu caranya adalah proses pembelajaran yang tepat digunakan oleh guru untuk meningkatkan pengetahuan dan keterampilan peserta didik. Proses pembelajaran yang berorientasi pada peserta didik dengan menggunakan model, metode serta strategi yang tepat.

Memasukai abad 21 atau disebut juga era revolusi industry 4.0 diperlukan kesiapan sumber daya manusia yang siap. Menurut Zubaidah (2019), salah satu keterampilan hidup yang diharapkan adalah soft skill, yaitu keterampilan 4C yang terdiri dari 
critical thinking and problem solving, collaboration, communication, creativity and innovation. Keterampilan ini sangat dibutuhkan dalam keterampilan Abad 21 di era Revolusi Industri 4.0.

Berpikir kritis adalah proses mental untuk menganalisis atau mengevaluasi suatu informasi (Usman et al., 2017). Keuntungan yang didapatkan sewaktu kita berpikir kritis adalah kita bisa menilai bobot ketepatan dan kebenaran suatu pernyataan dan tidak mudah menelan setiap informasi tanpa memikirkan terlebih dahulu apa yang sedang disampaikan.

Berpikir kreatif dapat menstimulasi suatu pemikiran menghasilkan bermacam-macam kemungkinan ide dan cara secara luas dan beragam Kreativitas berkaitan dengan kemampuan untuk menemukan kaitankaitan yang baru, kemampuan melihat sesuatu dari sudut pandang yang baru, dan kemampuan untuk membentuk kombinasikombinasi dari banyak konsep yang ada pada pikiran (Usman \& Ratnasari, 2019). Dengan demikian melatih kreativitas siswa sangat diperlukan untuk mempersiapkan mereka menghadapi masa depannya.

Model pembelajaran mind mapping atau peta pemikiran merupakan salah satu model pembelajaran yang tepat untuk meningkatkan keterampilan berpikir kreatif siswa (Wulandari et al., 2019). Pada praktiknya model pembelajaran ini menggunakan pengingat-pengingat visual dan sensorik dalam suatu pola dari ide-ide yang berkaitan (Buzan, 2008). Model pembelajaran ini yang berfungsi untuk menuangkan ide-ide atau gagasan yang menimbulkan percikan-percikan kreatifitas yang diperoleh otak yang bertujuan untuk meningkatkan keterampilan berpikir kreatif siswa. Model ini merupakan model yang sering digunakan guru dalam proses pembelajaran dalam upaya menumbuhkan kreativitas dan prestasi siswa.

Berdasarkan hasil observasi di SMAN 5 Kota Serang diketahui bahwa pada proses pembelajaran biologi yang membahas materi keanekaragaman hayati guru menerapkan model pembelajaran mind map. Dari hasil wawancara diketahui tujuan guru menerap kan model tersebut adalah untuk merangkai materi pembelajaran agar tersusun secara sistematis. Ada beberapa keunggulan mind map yang dikemukakan (Syam, 2015) diantaranya (1) meningktakan kinerja manajemen pengetahuan, memaksimalkan sistem kerja otak, (3) saling berhubungan satu sama lain sehingga semakin banyak ide dan informasi yang dapat dijelaskan, (4) memacu kreativitas, sederhana, dan mudah dikerjakan. Dengan demikian mind map dapat melatih kemampuan berpikir kritis dan kreativitas siswa.

Berdasarkan penjelasan tersebut maka diperlukan kajian untuk mengetahui hubungan antara keterampilan berpikir kritis dengan keterampilan berpikir kreatif melalu model pembelajaran mind map.

\section{METODE PENELITIAN}

Metode penelitian yang digunakan dalam penelitian ini adalah metode deskriptif korelasional. Pada penelitian ini akan dilihat hubungan dari variabel $\mathrm{X}$ berupa kemampuan berpikir kritis dan variabel $\mathrm{Y}$ berupa kreativitas siswa. Penelitian ini dilaksanakan di SMAN 5 Kota Serang pada 14 Agustus sampai 4 September tahun ajaran 2019/2010. Populasi dalam penelitian ini adalah seluruh kelas $\mathrm{X}$ MIPA sedangkan sampel yang digunakan adalah kelas X MIPA 5 yang diambil dengan teknik random sampling.

Teknik pengumpulan data yang dilakukan ini yaitu dengan menggunakan tes dan non tes. 
Instrumen tes digunakan untuk mengetahui kemampuan berpikir kritis berupa uraian dengan jumlah 5 soal. Sementara non tes menggunakan mind map untuk mengetahui kreativitas siswa.

Uji instrumen yang diperlukan yaitu validitas, reabilitas, daya pembeda, dan tingkat kesukaran yang hasilnya dianalisis menggunakan software ANATES 4.0.9. Uji instrumen ini dilakukan pada kelas XII IPA 6 yang telah memperoleh materi tentang keanekaragaman hayati.

\section{HASIL DAN PEMBAHASAN}

Profil kemampuan berpikir kritis siswa Hasil penilaian kemampuan berpikir kritis diinterpretasi ke dalam kategori penilaian menurut dengan modifikasi kategori berupa sangat kritis, kritis, cukup, kurang kritis dan sangat kurang. Hasil penilaian tersebut dapat dilihat pada Gambar 1.

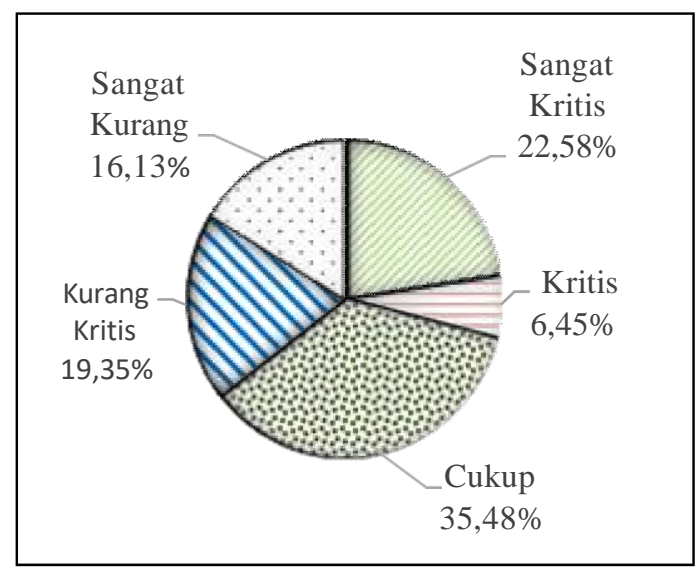

Gambar 1. Persentase Hasil Penilaian Kemampuan Berpikir Kritis

Berdasarkan hasil pengukuran tingkatan berpikir kritis siswa tergolong cukup dengan persentase nilai sebesar 35,48\%. Kemampuan berpikir kritis siswa yang secara umum berada pada kategori cukup menunjukan bahwa keaktifan siswa dalam kegiatan pembelajaran di kelas masih standar dan hanya didominasi oleh siswasiswa tertentu saja. Aktivitas belajar siswa di kelas X MIPA 5 ini dapat dilihat melalui kegiatan pembelajaran seperti diskusi kelompok, presentasi hasil belajar, tanya jawab, menyimak dan menyimpulkan. Ketika mengerjakan soal, ternyata masih ditemukan kurang relevannya antara jawaban dengan pertanyaan yang diajukan, sehingga menyiratkan bahwa tidak semua siswa memahami konsep keanekaragaman hayati.

Siswa yang masuk dalam kategori kritis dan sangat kritis dalam penelitian ini berarti menununjukkan siswa sudah mampu memadukan antara proses berpikir kritisnya dengan pemahaman konsep yang ada. Hal ini terlihat dari jawaban siswa yang sudah relevan dengan pertanyaan yang diajukan. Siswa yang masuk kategori ini juga sudah mampu memberi keputusan yang logis terkait hal-hal yang harus dilakukan ketika menemukan suatu permsalahan. Kemampuan berpikir kritis yang terlihat berdasarkan jawaban siswa dalam menyelesaikan soal sebenarnya sudah dilatih dalam proses belajar. Misalnya, ketika kegiatan diskusi kelompok siswa dituntut ikut berkontribusi menyelesaikan suatu persoalan atau menyelesaikan lembar kerja. Kegiatan diskusi untuk memecahkan masalah atau Problem Based Learning (PBL) berpengaruh terhadap keterampilan berpikir kritis siswa (Ayuningrum et al., 2010). Kontribusi siswa yang diberikan dalam kelompok nantinya akan meningkatkan kemampuan berpikir kritis siswa.

Siswa yang masuk dalam kategori kurang kritis dan sangat kurang dalam penelitian ini cenderung memiliki jawaban yang tidak sesuai dengan pertanyaan. Tidak relevannya jawaban siswa terlihat ketika siswa diberikan pertanyaan mengenai tipe fauna disertai dengan argumen. Siswa menjawab dengan tidak memberikan argument sesuai petununjuk soal. Hal ini membuktikan kemampuan berpikir kritis siswa yang kurang dan perlu dilatih dengan cara 
pemberian soal atau pertanyaan. Pemberian pertanyaan dapat menstimulasi siswa untuk menjawab dan berargumen (Usman et al., 2017). Hal ini sesuai dengan pendapat (Ennis, 2013) yang menyatakan bahwa berargumen merupakan dasar dari proses berpikir dalam keterampilan berpikir kritis.

Tinggi rendahnya kemampuan berpikir kritis siswa juga dipengaruhi beberapa faktor. Faktor yang ikut mempengaruhi kemampuan berpikir kritis siswa diantaranya yaitu faktor eksternal dan internal. Faktor eksternal (faktor dari luar) menurut Egok (2016), meliputi lingkungan keluarga, lingkungan sekolah dan lingkungan masyarakat. Tidak dapat dipungkiri bahwa lingkungan eksternal seperti lingkungan belajar siswa di sekolah ikut mempengaruhi kemampuan berpikir kritis.

Kondisi lingkungan ini terlihat dari kegiatan pembelajaran misalnya, aktivitas tanya jawab di kelas. Siswa masih banyak yang malu dan beranggapan takut salah dalam menjawab sehingga hanya sedikit siswa yang menjawab pertanyaan. Sebaliknya, dalam diskusi kelompok atau kegiatan lainnya ada siswa yang beranimengajukan pertanyaan ketika tidak memahami suatu persoalan sehingga siswa yang lain cenderung ikut aktif mengajukan pertanyaan. Kecenderungan siswa dalam bertanya mampu meningkatkan kemampuan berpikirnya. Hal ini sesuai Hariyani (2012), yang menyatakan bahwa melalui bertanya pengetahuan siswa bertambah. Selain faktor eksternal, ada beberapa faktor internal yang juga ikut mempengaruhi kemampuan berpikir kritis.

Faktor internal yang dapat meningkatkan atau menurunkan kemampuan berpikir kritis diantaranya kondisi fisik, keyakinan diri atau motivasi, kecemasan dan perkembangan intelektual atau kecerdasan (Faiz, 2012).
Pelajaran biologi di kelas $X$ MIPA 5 terjadwal pada siang hari setelah jam istirahat namun sebelumnya berlangsung pembelajaran lain yang membuat otak bekerja sedikit cukup keras shingga ikut mempengaruhi konsentrasi beberapa siswa dalam berpikir dan menyerap materi yang dipelajari. Kecerdasan dan daya serap yang dimiliki setiap individu juga pasti berbedabeda. Hal ini dibuktikan melalui soal postest sebagai alat evaluasi belajar yang menunjukkan siswa bervariasi dalam menjawab pertanyaan. Variasi jawaban siswa misalnya dapat dilihat ketika siswa menjelaskan strategi pengelolaan yang dapat dilakukan untuk melestarikan keanekaragaman hayati. Selain itu, motivasi juga ikut berperan dalam meningkatkan atau menurunkan kemampuan berpikir kritis siswa.

Dorongan yang diberikan guru akan membantu antusias siswa dalam belajar akan tetapi sebenarnya respon positif yang diberikan siswa sebagian besar berasal dari semangat dan keingintahuannya. Pada pertemuan pertama, siswa terlihat kurang termotivasi akan tetapi pada pertemuan selanjutnya sebagian besar siswa merespon dengan positif dan semangat setelah guru memberikan apresiasi. Semangat dan rasa ingin tahu siswa yang timbul dalam dirinya akan mendorong siswa tersebut untuk dapat menemukan jawaban dalam mengerjakan soal, sehingga ada kaitan antara motivasi dengan proses berpikir siswa.

Pada dasarnya, isi dari soal kemampuan berpikir kritis yang menjadi bahan evaluasi diakhir merupakan konsep yang sudah pernah dipelajari selama proses pembelajaran. Soal postest ini dibuat berdasarkan indikator yang ada pada kemampuan berpikir kritis. Selain dinilai dan dimasukkan ke dalam kategori kemampuan berpikir kritis, persentase 
kemampuan berpikir kritis juga dihitung pada setiap indikatornya.Hasil kemampuan berpikir kritis pada tiap indikator dapat dilihat pada Gambar 2.



Gambar 2. Persentase Kemampuan Berpikir Kritis Setiap Indikator

Persentase tertinggi yang didapatkan soal dengan indikator mengidentifikasi asumsi, menunjukkan bahwa siswa mampu memberikan penjelasan lebih lanjut terkait sebuah permasalahan yang ada. Hal ini terlihat dari jawaban siswa yang dapat menjelaskan mengenai "dampak negatif yang akan terjadi apabila proyek pembangunan jalan yang membelah hutan taman nasional tetap dilakukan". Ketercapaian tertinggi yang didapat pada indikator ini memang menunjukkan bahwa soal berada pada kategori mudah sehingga sebagian besar siswa cenderung dapat menjawab soal tersebut. Selain itu, soal dengan indikator ini lebih menekankan pada pendapat siswa sehingga siswa dapat menuangkan apa yang ada di pikiran berdasarkan informasi dan pengalaman belajarnya.

Indikator soal berupa menginduksi dan mempertimbangkan hasil induksi maksudnya siswa dituntut untuk mengemukakan atau menarik kesimpulan sesuai fakta atau konteks yang ada. Soal yang dibuat dengan indikator tersebut termasuk ke dalam tingkat kesukaran yang sedang akan tetapi soal dengan indikator ini justru memperoleh persentase terendah $(58,06)$ dibandingkan dengan indikator pertama (menganalisis pertanyaan) yang menunjukan soal pada kategori sukar. Hal ini berarti sebagian besar siswa masih belum dapat menarik kesimpulan berdasarkan korelasi atau keterkaitan yang diminta pada soal.

Jawaban yang diberikan siswa pada soal dengan indikator menginduksi dan mempertimbangkan hasil induksi ternyata masih banyak yang tidak sesuai dengan pertanyaan. Sebagian besar siswa kesulitan memahami ilustrasi gambar hutan yaitu terkait nilai ekologisnya terhadap kondisi yang diilustrasikan gambar kedua. Jawaban siswa pada soal ini menunjukkan kemampuan berpikir kritis siswa yaitu dalam menarik sebuah kesimpulan masih kurang. Padahal, jika siswa memahami secara mendalam tentang manfaat dan nilai-nilai keanekaragaman hayati siswa akan dengan mudah mengaitkan ilustrasi tersebut. Letak kesalahan sebagian besar siswa yaitu bukan menjawab keterkaitan hubungan yang ada pada kedua gambar lalu menyimpulkannya secara general, namun menjelaskan satu persatu makna dari gambar tersebut.

\section{Profil Kreativitas Siswa dalam Membuat Mind Map}

Hasil penilaian kreativitas pada siswa didapatkan melalui pembuatan mind map. Mind map dibuat mengenai materi yang telah dipelajari yaitu tentang keanekaragaman hayati. Kreativitas siswa yang tersalur melalui mind map ini dinilai berdasarkan indikator kreativitas dan mind map, yaitu originality, fluency \& 
flexibility, \& elaboration (Usman \& Ratnasari, 2019). Hasil penilaian kreativitas ini diinterpretasi ke dalam 5 kategori penilaian diantaranya sangat kreatif, kreatif, cukup, kurang kreatif, dan sangat kurang. Hasil penilaian kriteria kreativitas dan mind map dapat dilihat pada Gambar 3.

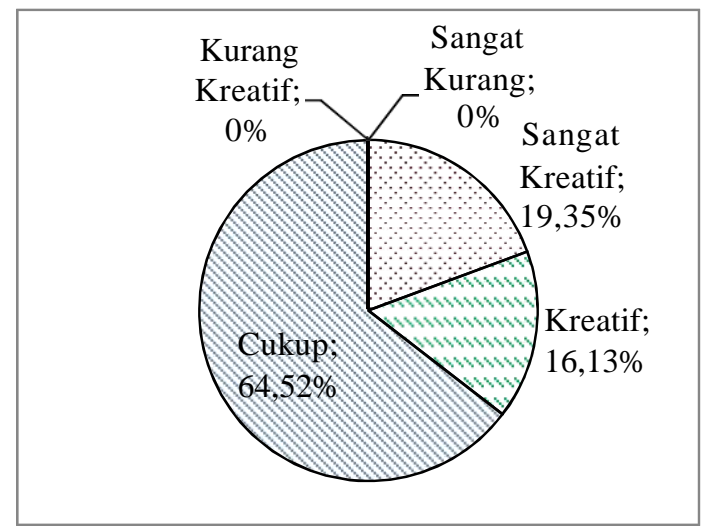

Gambar 3. Persentase Hasil Penilaian Kreativitas dalam Membuat Mind Map

Hasil penilaian kreativitas siswa kelas $X$ MIPA 5 berada pada kategori sangat kreatif, kreatif, dan cukup sedangkan untuk kategori kurang kreatif dan sangat kurang tidak muncul atau mendapatkan persentase 0\% (Gambar 3). Artinya, semua siswa kelas $X$ MIPA 5 memiliki kreativitas dalam belajar. Persentase tertinggi nilai hasil kreativitas diperoleh siswa dengan kategori cukup yaitu mencapai $64,52 \%$. Sisanya yaitu $19,35 \%$ dengan kategori sangat kreatif dan 16,13\% dengan kategori kreatif.

Sebenarnya semua siswa tersebut memiliki potensi dalam dirinya untuk kreatif hanya saja potensi yang dimiliki berbeda-beda dan perlu dikembangkan. Pernyataan ini sejalan dengan Budiyarti (2015), yang menyatakan bahwa setiap orang pada dasarnya memiliki kreativitas pada dirinya meskipun dengan kadar yang berbeda. Salah satu bentuk pengembangan kreativitas siswa dalam belajar yaitu dengan memanfaatkan metode belajar berupa pembuatan mind map yang dilakukan pada pertemuan kedua. Fakta menjelaskan bahwa siswa memiliki antusias yang cukup ketika pembuatan mind map. Hal ini terlihat bahwa pada pertemuan kedua yang menunjukkan semangat siswa tinggi (termotivasi), sehingga kondisi seperti ini sangat membantu siswa mengerahkan kemampuannya dalam berkreativitas melalui mind map.

Mind map menghubungkan ide baru dan unik dengan ide yang sudah ada sehingga menimbulkan tindakan spesifik yang dilakukan oleh siswa. Darusman (2014), dalam jurnalnya menyatakan bahwa mind map adalah metode pembelajaran yang dirancang untuk mengembangkan pengetahuan siswa dengan kegiatan kreatif menyusun ide-ide pokok dari sebuah konsep menjadi sebuah peta pikiran. Penggunaan warna dan simbol-simbol yang menarik dalam membuat mind map menurut Siregar (2014), dapat menciptakan pemetaan pikiran yang baru dan berbeda. Pemetaan pikiran ini merupakan produk kreatif yang dihasilkan oleh siswa dalam kegiatan belajar.

Kreativitas siswa penting untuk dikembangkan agar siswa dapat menghadapi suatu persoalan yang internal maupun global. Siswa dapat dikatakan kreatif apabila siswa tersebut mencapai suatu indikator kreativitas. Indikator yang dapat menilai kreativitas siswa dalam pembuatan mind map diantaranya originality (keaslian), fluency (kelancaran) \& flexibility (keluwesan), elaboration (penguraian), link (hubungan), structure (Struktur). Hasil penilaian kreativitas pada setiap indikatornya dapat dilihat pada Gambar 4. 




Gambar 4. Persentase Kreativitas pada Setiap Indikator.

Kreativitas siswa kelas X MIPA 5 berdasarkan Gambar 3.4 yang memiliki persentase tertinggi berada pada indikator elaboration (penguraian). Elaboration merupakan indikator yang menuntut siswa untuk mampu mengembangkan suatu gagasan (Darusman, 2014: 168). Pada penilaian indikator elaboration (penguraian) rata-rata siswa mendapatkan point maksimal yaitu 3 bahkan untuk siswa dengan kategori sangat kreatif semuanya mencapai indikator tersebut. Artinya, sebagian besar siswa kelas X MIPA 5 dapat menguraikan gagasannya. Penguraian gagasan ini dapat dilihat dari kemampuan siswa dalam membuat cabang sehingga, semakin banyak cabang yang dibuat maka semakin tinggi pula penilaian terhadap indikator elaboration.

Sebagian besar siswa ternyata sudah dapat membuat cabang antara 25-35 cabang atau lebih ketika membuat mind map sehingga, persentase indicator elaboration mencapai $87,1 \%$. Sebenarnya, ketercapaian tersebut juga dikarenakan pada pertemuan pertama diakhir pembelajaran siswa telah diminta untuk menyimpulkan mengenai materi yang telah dipelajari. Selain itu, guru juga memberi penguatan dengan membuat peta pemikiran di papan tulis sehingga siswa mengetahui pointpoint apa saja yang akan dicatat. Hal inilah yang membantu siswa untuk dapat menguraikan gagasannya melalui pembuatan cabang dalam mind map pada pertemuan berikutnya.

Indikator elaboration akan saling berkaitan dengan indikator structure dan link. Dilihat pada skor hasil penilaian kreativitas, sebagian siswa yang dapat mencapai indikator elaboration ratarata ikut dapat memenuhi indikator structure dan link. Hal ini karena adanya keterkaitan dalam penilaian pada indikator tersebut. Penilaian untuk indikator link (hubungan) menunjukan bahwa siswa dalam menguraikan antara gagasan yang satu dengan yang lain cukup dapat dimengerti. Indikator structure menekankan pada siswa agar membuat mind map sesuai dengan aturan pembuatannya.

Pembuatan cabang serta penulisan dalam mind map yang dilakukan sebagian siswa sudah sesuai dengan panduan pembuatan, akan tetapi sebagian siswa lainnya masih ada yang belum sesuai. Misalnya, pada indikator structure ukuran cabang ke cabang lainnya serta penggunaan warna pada satu cabang sudah terpenuhi oleh siswa namun masih ada satu cabang yang tidak dibuat melengkung. Selain itu, kata kunci yang digunakan masih ada yang tidak ditulis pada garis lengkung.

Hasil terendah pada kreativitas siswa dalam membuat mind map didapatkan pada indikator originality (keaslian) yaitu 63,44\%. Gunawan (2014), menyebutkan bahwa ciri-ciri orisinil yaitu selalu memikirkan masalah-masalah atau hal-hal yang tidak pernah terpikirkan orang lain. Indikator ini menuntut siswa untuk dapat berkreasi dan memiliki hasil karya yang berbeda dengan orang lain. Secara umum, seseorang selalu memikirkan masalah atau suatu hal yang juga dipikirkan oleh orang lain dan jarang biasanya setiap orang memiliki suatu pemikiran yang berbeda dengan orang lain. Hal ini terbukti dari hasil mind map yang dibuat siswa ternyata masih banyak ditemukan kesamaan antara siswa yang satu dengan yang lainnya. Dilihat dari mind map yang dibuat, siswa tersebut masih menyimpan kata kunci pada cabang yang sama dari orang lain atau umum. Selain itu, indikator originality pada mind map juga dilihat dari ada tidaknya simbol atau gambar yang digunakan.

Siswa kelas X MIPA 5 masih banyak yang belum menggunakan gambar atau simbol dalam pembuatan mind map untuk menunjukkan 
kreasinya. Padahal, penggunaan simbol dalam pembuatan mind map juga penting karena simbol ini digunakan sebagai pembeda dari yang lain. Hal ini ikut menurunkan penilaian kreativitas siswa terhadap indikator originality. Penggunaan simbol yang belum digunakan sebagian siswa tersebut disebabkan siswa banyak mengulur-ulur waktu yang mereka punya untuk membuat mind map sehingga sebagian siswa tidak sempat membuatnya. Pentingnya waktu yang digunakan juga dijelaskan Rahman (2018), bahwa waktu yang mendesak bagi siswa membuat siswa tidak terlalu matang saat merencanakan dan memikirkan ide.

Tinggi rendahnya kreativitas seseorang dipengaruhi oleh beberapa faktor. Faktor yang dapat mendorong peningkatan kreativitas yaitu berupa faktor internal dan faktor eksternal. Faktor eksternal yang terlihat ketika kegiatan pembelajaran yaitu diantaranya waktu yang dibutuhkan. Alokasi waktu diberikan untuk mengetahui kemampuan siswa menyelesaikan dengan cepat dan menuangkan konsep yang sudah dipelajari sebelumnya. Faktor berupa sarana belajar pun ikut berperan meningkatkan kreativitas siswa. Pada pembuatan mind map diperlukan peralatan yang cukup memadai seperti alat untuk menulis dan mewarnai sehingga siswa dapat bebas berkreasi. Selain faktor eksternal, kreativitas ikut dipengaruhi oleh faktor internal. Faktor internal yang ikut meningkatkan kreativitas yaitu dorongan belajar atau motivasi. Dorongan belajar atau motivasi siswa pada pertemuan kedua ini terlihat tinggi. Antusias siswa yang cukup positif ini mampu meningkatkan kreativitasnya dalam berkreasi.

Hubungan Kemampuan Berpikir Kritis dengan Kreativitas Siswa

Penelitian korelasi atau hubungan antara kemampuan berpikir kritis dengan kreativitas menggunakan analisis korelasi Pearson Product Moment dapat dilihat pada table 1 .

\begin{tabular}{cc}
\hline $\begin{array}{c}\text { Variable XY } \\
\text { (kemampuan berpikir } \\
\text { kritis dengan } \\
\text { kreativitas) }\end{array}$ & Nilai \\
\hline Signifikansi korelasi & $0.16<0.05$ \\
\hline
\end{tabular}

\begin{tabular}{lc}
\hline Koefisien korelasi $\left(\mathrm{r}_{\mathrm{xy}}\right)$ & 0.427 \\
Koefisien determinasi $\left(\mathrm{r}^{2}\right)$ & 0.183 \\
Regresi linier & $\mathrm{Y}=57.031+0.255 \mathrm{X}$ \\
\hline
\end{tabular}

Hasil analisis korelasi antara variabel $\mathrm{X}$ (kemampuan berpikir kritis) dengan variabel Y (kreativitas) diperoleh nilai signifikansi 0,016 < 0,05 artinya terdapat hubungan antara kedua variabel. Nilai $r_{x y}$ (koefisien korelasi) pada penelitian mendapatkan angka sebesar 0,427. Hal ini menunjukkan bahwa hubungan kemampuan berpikir kritis dengan kreativitas termasuk ke dalam kategori tingkat hubungan yang sedang. Hubungan yang sedang antara kedua variabel berdasarkan fakta di lapangan disebabkan oleh kurang optimalnya siswa dalam menggunakan kemampuan berpikir kritis dan kreativitasnya selama mengikuti serangkaian pembelajaran di kelas. Hal ini dibuktikan dari hasil posttest kemampuan berpikir kritis dan kreativitas siswa melalui mind map yang menyatakan bahwa rata-rata siswa kelas $\mathrm{X}$ MIPA 5 berada dalam kategori cukup. Artinya pembelajaran di kelas masih terlihat biasa saja dan keaktifannya hanya didominasi oleh siswasiswa tertentu. Oleh karena itu, keterkaitan antara berpikir kritis dengan kreativitas siswa di kelas X MIPA 5 tidak rendah dan tidak pula tinggi.

Perhitungan statistik yang dilakukan untuk mengukur hubungan kemampuan berpikir kritis dengan kreativitas tidak berhenti sampai mencari nilai $\mathrm{r}_{\mathrm{xy}}$ (koefisien korelasi). Mencari koefisien determinasi dan uji regresi linier dalam perhitungan statistik ini juga diperlukan. Hal ini untuk mengetahui seberapa besar kontribusi kemampuan berpikir kritis terhadap kreativitas siswa dan untuk mengetahui secara pasti apakah perubahan nilai pada kemampuan berpikir kritis berbanding lurus dengan kreativitas.

Nilai koefisien determinasi $\left(\mathrm{r}^{2}\right)$ yang didapatkan dalam penelitian adalah 0,183 . Hal ini berarti kemampuan berpikir kritis memiliki kontribusi hanya sebesar 18,3\% terhadap kreativitas siswa. Kontribusi yang minim berdasarkan fakta di lapangan disebabkan oleh beberapa siswa yang kurang mengoptimalkan kegiatan pembelajaran seperti diskusi kelompok, tanya jawab dan menyimpulkan materi. Siswa juga kurang 
menyimak dengan baik informasi yang disampaikan guru dan teman sebayanya ketika tanya jawab dan menyimpulkan materi. Padahal, kegiatan pembelajaran seperti diskusi dan tanya jawab penting untuk melatih kemampuan berpikir kritis siswa dan membantu siswa dalam menuangkan kreativitasnya melalui mind map.

Kontribusi yang minim terhadap kreativitas juga salah satunya karena kreativitas sendiri sebenarnya tidak cukup hanya melibatkan kemampuan berpikir kritis saja. Kreativitas siswa juga dapat muncul jika kemampuan berpikir kreatif siswa ikut dilibatkan. Pernyataan ini didasari oleh pendapat yang mengemukakan bahwa berpikir kreatif dan kreativitas adalah dua hal yang saling bertemali sebab kemampuan berpikir kreatif, berpores kreatif, dan mampu menghasilkan produk kreatif merupakan konsep inti kreativitas (Abidin, 2016).

Sebagian besar lainnya yaitu sekitar $81,7 \%$ kontribusi terhadap kreativitas disebabkan oleh faktor lain. Faktor-faktor tersebut merupakan faktor internal dan eksternal yang ikut meningkatkan dan menurunkan kreativitas siswa. Salah satu faktor yang sangat berkontribusi dalam peningkatan kreativitas siswa yaitu motivasi. Hal ini sejalan dengan pendapat Abidin (2016), yang menyatakan bahwa motivasi intrinsik yang tinggi akan menjadi dasar terhadap sikap disiplin diri seseorang, hal ini akan membuat seseorang terbuka atas pengalaman baru yang dilaluinya sehingga dapat melahirkan ide baru. Hasil observasi menunjukkan bahwa siswa pada pertemuan kedua terlihat termotivasi untuk belajar jika dibandingkan dengan pertemuan sebelumnya. Antusias dan keinginan siswa yang muncul dari diri sendiri inilah yang mampu meningkatkan kreativitasnya dalam berkreasi.

Penelitian mengenai hubungan antara kemampuan berpikir kritis dengan kreativitas ini setelah perhitungan koefisien korelasi dan determinasi juga terlihat dari uji regresi. Hasil uji regresi linier didapatkan bahwa hubungan antara berpikir kritis dengan kreativitas berada dalam persamaan $\mathrm{Y}=57,031+0,255 \mathrm{X}$. Artinya kedua variabel saling mempengaruhi satu sama lain. Konstanta 57,031 dari persamaan $\mathrm{Y}=57,031+0,255 \mathrm{X}$ merupakan nilai dari kreativitas, artinya ketika kemampuan berpikir kritis siswa bernilai 0 maka nilai kreativitas siswa itu sendiri sebesar 57,03. Koefisien regresi yang menunjukkan angka 0,255 pada persamaan linier tersebut maksudnya adalah jika pada nilai kemampuan berpikir kritis bertambah $1 \%$ maka kreativitas siswa ikut bertambah sebesar 0,255.

Hubungan linier ini didapatkan karena adanya keterkaitan antara kedua variabel. Fakta menunjukkan kemampuan berpikir kritis yang memiliki persentase tertinggi yaitu terdapat pada indikator mengidentifikasi asumsi sedangkan persentase tertinggi kreativitas didapatkan indikator elaboration (penguraian). Indikator mengidentifikasi asumsi menekankan pada pendapat atau argumen yang dikemukakan siswa dan indikator elaboration menekankan pada pengembangan gagasan. Penguraian gagasan dalam mind map yang dikembangkan melalui pembuatan cabang memerlukan nalar atau kemampuan berpikir yang logis, sehingga penguraian gagasan yang dimuat dari cabang satu ke cabang berikutnya jelas dapat dipahami. Kemampuan dalam bernalar inilah yang dapat digunakan siswa dalam mengemukakan argumen. Hal ini sesuai dengan pendapat yang menyatakan bahwa kemampuan berargumen akan sangat berhubungan dengan kemampuan bernalar (berlogika) sehingga semakin benar logika 
yang digunakan maka argumentasi yang dibuat semakin kuat (Abidin, 2016).

\section{KESIMPULAN}

Hasil penelitian didapatkan bahwa terdapat hubungan antara kemampuan berpikir kritis dengan kreativitas siswa kelas $\mathrm{X}$ MIPA melalui mind map pada konsep keanekaragaman hayati di SMAN 5 Kota Serang. Hubungan antara kemampuan berpikir kritis dengan kreativitas tersebut memiliki nilai koefisien korelasi $\left(\mathrm{r}_{\mathrm{xy}}\right)$ sebesar 0,427 dengan kategori sedang. Kontribusi kemampuan berpikir krits siswa terhadap kreativitasnya hanya sebesar 18,3\%. Kemampuan berpikir kritis dengan kreativitas dalam penelitian ini memiliki hubungan linier yang terdapat dalam persamaan $\mathrm{Y}=57,031+0,255 \mathrm{X}$. Hal ini menunjukkan jika nilai kemampuan berpikir kritis siswa meningkat maka kreativitas siswa ikut bertambah.

\section{REFERENSI}

Ayuningrum, D., Mulyani, S., \& Susilowati, E. (2010). Implementation of Problem Based Learning (Pbl) To Student 'S Critical Thinking Skill on Protist Matter.

December, 82-90.

Buzan, T. (2008). Mind Map Untuk Meningkatkan Kreativitas. Gramedia Pustaka Utama.
Ennis, R. H. (2013). The Nature of Critical Thinking: Outlines of General Thinking Dispositions and Abilities.

http://www.criticalthinking.net/longdefiniti on.html

Syam, N. \& R. (2015). Penerapan Model Pembelajaran Mind Mapping dalam Meningkatkan Hasil Belajar pada Mata Pelajaran Ilmu Pengetahuan Sosial Siswa Kelas IV SDN 54 Kota Parepare. Jurnal Publikasi Pendidikan, 5(3), 184-197.

Usman, U. \&, \& Ratnasari, D. (2019). Student Perseption of Learning That Developing Creative. Didaktika Biologi: Jurnal Penelitian Pendidikan Biologi, 3, 27-35.

Usman, U., Susilowati, S., \& Widiyaningrum, P. (2017). Analisis Kesesuaian RPP terhadap Pelaksanaan Pembelajaran Biologi dalam Mengembangkan Keterampilan Berpikir Kritis Siswa. Journal of Innovative Science Education, 6(2), 243-251. https://doi.org/10.15294/jise.v6i2.15198

Wulandari, F. A., Mawardi, M., \& Wardani, K. W. (2019). Peningkatan Keterampilan Berpikir Kreatif Siswa Kelas 5 Menggunakan Model Mind Mapping. Jurnal Ilmiah Sekolah Dasar, 3(1), 10. https://doi.org/10.23887/jisd.v3i1.17174 